\title{
LIABILITY INSURANCE AND THE TORT IMMUNITY OF STATE AND LOCAL GOVERNMENT
}

\author{
Gerald R. GibBons*
}

TO AN increasing degree in recent years, state and local govern1 ment entities have been purchasing insurance to cover activities in which they engage in which they enjoy a sovereign immunity from tort liability. Why are government entities purchasing this insurance? Are they authorized to do so? Is the insurance enforceable? To what degree will this practice mitigate the harsh effects of the sovereign immunity doctrine? Will it play an important role in bringing about a general assumption of governmental liability? This article is directed to a discussion of these questions in the light of the growing body of decisional law in this area.

The doctrine of sovereign immunity, which exempts government entities from liability for the torts of its agents, has been under critical attack for more than three decades. ${ }^{1}$ On the federal level, this criticism eventuated in the passage of the Federal Tort Claims Act of $1946 .^{2}$ On the state and local levels, however, progress has been slow, and the immunity doctrine continues to demonstrate considerable vitality.

Initially, a distinction should be drawn between state and county governments and their subentities on the one hand, and municipal governments and their subentities on the other. In general, the broad mantle of immunity covers all activities of state governments, ${ }^{3}$ in-

* A.B. 1954, LL.B. 1956, Duke University. Assistant Professor of Law, Mercer University.

${ }^{2}$ The classical reference in this field is Borchard, Government Liability in Tort, 34 YALE L.J. I, 129, 229 (1924); 36 id. $1,757,1039$ (1928).

${ }^{2} 60$ Stat. 842 (1946), 28 V.S.C. \$ 1346 ( 1952 ). See Wright, The Federal TORT Clams ACT (1957). For a comparative treatment of the laws of other countries, see StreEt, Governmental LiaBility 1-24 (1953); Blachly \& Oatman, Approaches to Governmental Liability in Tort: A Comparative Survey, 9 LAW \& CoNTEMP. Prod. 181 (1942); Wade, Liability of the Central Government of the United Kingdom, 29 N.Y.U.L. REv. I416 (1954).

${ }^{3}$ See Nutting, Legislative Practice Regarding Tort Claims Against the State, 4 Mo. L. REv. I (1939), which surveys the constitutional, statutory, and judicial materials in a generalized fashion; and Leflar \& Kantrowitz, Tort Liability of the States, 29 N.Y.U.L. REv. 1363 (1945), which briefly summarizes the highlights in each state. 
cluding such subentities as highway commissions, state universities, and special subdivisions such as school and irrigation districts. ${ }^{4}$ Immunity has usually also been held to extend to all activities of county governments, including, inter alia, their public schools, hospitals, and road commissions. ${ }^{5}$ While nearly every state has authorized some compensation for at least limited classes of the tort victims of its agents, only a few have undertaken to accomplish this systematically. ${ }^{6}$ In most states, only piecemeal exceptions to the sovereign immunity doctrine have been carved out by statute. ${ }^{7}$

The immunity enjoyed by municipal government entities is different, however, in that it has never been complete. It has existed for only those activities which have been judicially labeled "governmental," as distinguished from "corporate," functions. ${ }^{8}$ Apparently, the purpose has been to confine the protection afforded to only those activities which

See also Anderson, Claims Against the State, 7 VAND. L. Rev. 234 (1954); Eckert, Another Decade of State Immunity to Suit, 2 ARK. L. REv. 375 (1948); Herzog, Liability of the State of New York for Governmental Functions, Io SYRAcUSE L. REv. 30 (1958); Lloyd, Le Roi Est Mort, Vive le Roi, 24 N.Y.U.L.Q. REv. 38 (1949); Peterson, Governmental Responsibility for Torts in Minnesota, 26 MinN. L. REv. 293, 480, 613 700, 854 (1942); Shnmate, Tort Claims A gainst State Government, 9 LAW \& Contemp. Prob. 242 (1942); Van Alstyne, Claims Against Public Entities: Chaos in California, 6 U.C.L.A.L. REv. 205 (1959); Waterman, One Hundred Years of a State's Immunity from Suit, I4 TEXAS L. REV. I35 (1936).

4As to school districts, see Annot., 160 A.L.R. 53 (1946). See also Musselman, Michigan Law on the Liability of School Districts for Torts, 2 U. DET. L. J. 63 (1933); Seitz, School District Responsibility for Negligent Supervision of Pupils, 25 MARQ. L. REV. II5 (I94I).

${ }^{5}$ See Kneir, The Legal Nature and Status of the American County, 14 MinN. L. REv. I4I (1930).

${ }^{\circ}$ New York has gone the farthest in the assumption of governmental liability. See Herzog, supra note 3 ; Lloyd, supra note 3. California and Illinois have also progressed farther in this regard than most other states.

${ }^{7}$ See Leflar \& Kantrowitz, supra note 3.

${ }^{8}$ See, generally, Antieau, The Tort Liability of American Municipalities, $40 \mathrm{Kx}$. L.J. I3I (1952); Barnett, The Foundations of the Distinction Between Public and Private Functions, I6 ORE. L. REv. 250 (1937); Dodridge, The Distinction Between Governmental and Proprietary Functions of Municipal Corporations, $23 \mathrm{MICH}$. L. REv. 325 (1925); Fuller \& Casner, Municipal Tort Liability in Action, 54 Harv. L. REv. 437 (1941); Gardner, An Inquiry Into the Principles of Municipal Responsibility in General Assumpsit and Tort, 7 VAND. L. REv. 753 (1955); Harno, Tort Immunity of Municipal Corporations, 4 ILI. L.Q. 28 (192I); Repko, American Legal Commentary on the Doctrines of Municipal Tort Liability, 9 LAW \& ConTEMP. PROB. 214 (1942); Seasongood, Municipal Corporations: Objections to the Governmental or Proprietary Test, 22 VA. L. REv. 910 (1936); Smith, Municipal Tort Liability, 48 MICH. L. REv. 4I (1949); Warp, The Law and Administration of Municipal Tort Liability, 28 VA. L. Rev. 360 (1942); Warp, Tort Liability Problems of Small Municipalities, 9 LAW \& Contemp. Prob. 363 (1942). 
have traditionally been considered "necessary" to government, and to exclude from coverage those activities which are merely conveniently carried on by government instead of by private enterprise. This nineteenth-century dichotomy was the judicial compromise struck between complete protection of public funds and complete protection of individuals tortiously injured by government agents. Both the basis of the distinction and its application, which has been difficult and artificial, have widely been regarded as less than satisfactory. ${ }^{9}$

Perhaps the strongest argument for the abandonment of the sovereign immunity doctrine is its inconsistency with the modern socioethical notion that the risk of wrongful injury should not be borne by the individual upon whom the misadventure fortuitously falls, but by society as a whole. ${ }^{10}$ Thus, it has been urged that compensation of government tort victims should be viewed as a justifiable and expectable cost of modern government. ${ }^{11}$ A means of equitably distributing the burden of the risk has been available to the federal and state governments and even to large cities in the form of taxation. And even though smaller units of government, with their greatly limited independent taxing power, have been unable to accommodate unlimited tort liability by this means alone, the commercial development of liability insurance has afforded them, too, a feasible device for spreading the burden of these risks. ${ }^{12}$

\footnotetext{
${ }^{\circ}$ See Repko, supra note 8; Seasongood, supra note 8.

${ }^{10}$ Another reason which is often urged for the abandonment of the sovereign immunity doctrine is the more extensive activity of government which results in a greater likelihood of injuries to individuals. This, of course, is clearly true for the national government; but there, immunity from tort liability has been restricted by statute. See note 2 supra.

${ }^{11}$ Although this attack against sovereign immunity may be denounced as "welfarism," actually it is this reasoning that justifes the doctrine of respondeat superior as applied to private corporations. The initial loss suffered by business employers is shifted to the public as consumers by way of higher prices for goods and services. See Douglas, Vicarious Liability and Administration of Risk, 38 YALE L.J. 583, 720 (1929); Feezer, Capacity to Bear Loss as a Factor in the Decissons of Certain Types of Tort Cases, 78 U. PA. L. REv. 805 (1930). At this level of comparison, a better case can probably be made for the distribution of risk through taxation than through the economic system, since taxation, being based on "progressive" principles, is more equitable in its risk distribution.

${ }^{18}$ Whether the funds of such governmental entities are appropriated by the legislature or obtained through taxation, they are budgeted. Tort claims against a government entity cannot be predicted in advance as to amounts, unless it is quite large. For example, a school district may go ten years without incurring a sizable tort claim, and then in one year, several serious school-bus accidents may eventuate in damages exceeding one hundred thousand dollars. With insurance, the total cost can be. spread out; the yearly premium can be estimated and provided for in the budget.
} 
As the proposal to shift losses arising from governmentally inflicted torts from the injured individual to the public at large gains wider acceptance, the immunity doctrine should suffer a corresponding restriction. Unfortunately, however, this area has been characterized by judicial obstructionism and legislative inertia. ${ }^{13}$ Courts have generally evidenced little disposition to alter the doctrine of sovereign immunity substantially; and as long as there are no organized pressure groups protecting the interests of those injured by the tortious actions of governnent agents, little can be expected from state legislatures. Modification of the sovereign immunity doctrine will instead probably await recognition by the insurance industry of the enlarged volume of business that would ensue should the doctrine be vitiated and consequent efforts on the part of the industry legislatively to hasten its decline and eventual demise.

Although the existence of insurance as a feasible risk-distribution device is the most persuasive reason for modifying the sovereign immunity doctrine and the insurance industry. the most likely spur of future legislation, the fact that government entities have been purchasing liability insurance, too, may play an important role to this end. At least this is the opinion of some commentators: ${ }^{14}$

By far the most significant development in the state tort field in recent years is the use of liability insurance both as a substitute for and a supplement to governmental liability. ... All indications are that governmental tort immunity is on the way out as a part of the American legal system, but the way out is a slow and circuitous one. . . Our law of torts preserves its ruggedly individualized façade of formal language while at the same time it gradually becomes in fact an adjunct of the law and practice of insurance, either private or social. There is much evidence that this gradual transition is what is beginning to happen, and will continue to happen, in the area of state and local governmental liability in tort.

A variety of reasons nay impel government officials to purchase liability insurance to cover immune activities:

I. The purpose of the insurance may be to obtain the carrier's services in defending suits against the government entity.

2. The law relating to the particular activity insured may be unclear as to the matter of immunity. The purpose of the insurance, then, may be to place the risk of an adverse judicial determination on the carrier; and even where immunity presently clearly attaches, the carrier would

\footnotetext{
${ }^{28}$ See note 54 infra.

"Leflar \& Kantrowitz, supra note 3 , at 1413-15.
} 
bear the risk that the law might be modified during the term of the contract.

3. The purpose of the insurance may be to protect members of the public injured by government employees.

4. Finally, the purpose of the insurance may be to protect government agents who remain personally liable for their torts.

To satisfy the first two suggested purposes, the carrier need assume only a limited responsibility; to achieve the last two, however, assumption of full liability would be necessary. The first purpose suggested would, in the light of the doctrine of sovereign immunity, be of little consequence were it not coupled with a duty to investigate claims. Although unnecessary for a totally immune state entity, this service would be useful to a municipal government entity. The second purpose suggested, too, would generally be entertained only by a municipal government entity engaging in activities only partially immune. Neither of the two purposes suggested, however, would normally appear to be of sufficient moment to warrant the purchase of insurance. But since municipal government entities ordinarily purchase liability insurance covering nonimmune activities, coverage for immune activities might well also be included and the limited additional duties assumed by the carrier for a small extra premium charge. ${ }^{16}$ The difficulty of discriminating the two types of activities may render this arrangement even more practical and convenient. ${ }^{16}$

Where full liability of the carrier is sought, as would seem to be the intent of state government entities purchasing insurance, ${ }^{17}$ the

${ }^{28}$ The fact that such arrangements have been made between carriers and municipal government entities was established by the writer of the Note, 33 MiNN. L. REv. 634 ( 1949 ).

${ }^{10}$ The difficulty is easily seen when a city wishes to insure a truck which is sometimes engaged in activities to which sovereign immunity attaches and is sometimes used for nonimmune activities.

${ }^{17} \mathrm{~A}$ resort to logic has been necessary to establish the probable intentions of the parties because their intentions have not been spelled out in the contract. Carriers have used uniform liability policies which provide that their duty to pay is limited to the extent of the liability imposed by law on the insured, which, if sovereign immunity attaches, is nonexistent. Further, because the carrier, under most policies, has the exclusive right to defend suits against the insured, its counsel is careful to avoid the appearance of any evidence in the record that it intended to be linble on the policy. On the other hand, in no case was evidence introduced by the injured plaintiff on this point by testimony of either the government entity's or the carrier's agents who negotiated the contract, although it would seem that such evidence would be admissible under the "ambiguity" exception to the parole evidence rule. Moreover, there has ncver been any attempt by the plaintiff to show, comparing the premium rates charged in the policy in suit with those on policies involving no sovereign immunity, that the carrier con- 
primary motivation is probably protection of government agents rather than protection of the general public, although both ends may simultaneously be served. The insurance is envisaged as a type of fringe employee benefit. Because most of the cases involving governmental immunity arise out of motor vehicle accidents-nearly half of them school buses-this rationale seems most plausible. Without additional pressure, however, insurance is not likely to be purchased for other than such limited activities. ${ }^{18}$

An issue occasionally presenting itself in this area is whether or not the purchase of insurance to protect against liability growing out of the performance of immune functions is within the authority of government officials. If not, there arises the further issue of the standing of the carrier to plead this matter as a defense. While the government entity or the taxpayers have such a privilege, it would seem proper to deny it to the carrier on grounds of estoppel. Actually, however, estoppel has seldom been mentioned by the courts, apparently because the carrier has appeared only as counsel for the government entity. ${ }^{19}$ As a result, the

tracted for liability. In several cases, the plaintiff alleged that the government entity paid the same rates for its policy as did nonimmune insureds, but these cases never proceeded beyond the demurrer stage. See, e.g., Schulte v. Hartford Acc. \& Indem. Co., ro2 F. Supp. 681 (D. Minn. 1951). In two cases, the carriers defended suits by arguing that the premium rates paid by the government entity were lowered because of its sovereign immunity. Burns v. American Cas. Co., 127 Cal. App.2d r98, 273 P.2d 605 (1954); Brooks v. Clark County, 279 Ky. 549, 180 S.W.2d 300 (1944). It should not be assumed that these were the only cases in which the argument could have been advanced, however, for carriers have consistently won without this defense.

In practically no cases, then, with the exception of those involving an endorsement on the policy by the carrier promising not to raise the defense (see note 62 infra), have the courts had explicit evidence as to the intentions of the parties concerning the carrier's liability. The courts have generally assumed that liability was intended, but have decided the cases on the ground that the government entities have no power to waive their sovereign immunity. Nevertheless, it is likely that a judicial suspicion that full liability on the part of the carrier was not intended is a potent exculpating factor. If, however, the courts should treat the sovereign immunity of the insured as obviating the requirement that the injured party obtain a judgment against the insured prior to bringing suit against the carrier, carriers would be forced to be more explicit with respect to their intent in this regard. See note 47 infra. Instead, the courts have, in effect, placed this burden on the government entity by denying recovery on the insurance policy absent an explicit provision by which the carrier promises not to raise the defense of immunity. And even then, the courts have held this promise unenforceable. See note $6_{3}$ infra.

${ }^{18}$ These problems have received some attention elsewhere. See David, Tort Liability of Local Government, 6 U.C.L.A.L. REV. 1, 45-52 (1959); James \& Thornton, The Impact of Insurance on the Law of Torts, 15 LAW \& CoNTEMP. ProB. 43I (1950); Comments, 34 NEB. L. Rev. 78 (1955); 54 MICH. L. REv. 404 (1956) ; 33 MinN. L. REv. 634 (1949).

${ }^{10}$ In one case where the carrier was sued in a direct action, the court ruled that it 
spectacle of the carrier pleading the illegality of its own contract on the grounds of an alleged governmental disability, while still retaining the premiums ${ }^{20}$ has not disturbed judicial equanimity.

Adverting once more to the major issue, however, it is to be noted that in most states statutes now authorize the purchase of liability insurance covering specific immune governmental activities. ${ }^{21}$ But absent such authorization, the courts have held the purchase to be ultra vires $^{22}$ as well as a wasteful, unnecessary expenditure of public funds. ${ }^{23}$ Of incidental interest in this connection are the cases where the government sues the carrier for restitution of past premium payments after the courts have barred an injured plaintiff from recovery on the policy because its purchase was unauthorized. While earlier the carrier's attorneys had argued that the contract was ultra vires, they now struggle

could not plead the government entity's lack of authority. McCaleb v. Continental Cas. Co., 132 Tex. 65, 116 S.W.2d 679 (1938). However, with the exception of Thomas v. Broadlands Community School Dist, 348 Ill. App. 567, 109 N.E.2d 636 (1952), where the defendant was the immune government entity, but the carrier was conducting the defense, the courts have concluded that the defense can be raised. The fact that the carrier and the insured have conflicting interests on this issue has not persuaded the courts to upset the form of the action, which is theoretically against the government entity.

${ }^{30}$ Of course, carriers may, as a gesture of good faith, tender the premiums paid to the court when they raise the lack-of-authority defense, but this is hardly satisfactory. The essence of the insurance contract is that the carrier accepts a small fee for assuming the unlikely risk of a large damage recovery. If carriers pay the small claims and dodge the big suits on the lack-of-authority issue, while collecting rcgular premium rates, the return of a handful of premiums is a small cost for what must be a lucrative business. Nor does the return of premiums place all of the affected parties in stattl quo ante. Consider the parties who1n the insurance was intended to benefit-the injured and only partly compensated plaintiff and the tortfeasor-government agent who may be forced to bear the burden alone. Because the cases are decided on the lack-of-authority issue rather than on general principles of restitution, these factors may be legally irrelevant, but they are, nonetheless, highly important practically.

${ }^{21}$ See notes 27-43 infra.

${ }_{22}$ Hartford Acc. \& Indem. Co. v. Wainscott, 41 Ariz. 439, 19 P.2d 328 (1933); Burns v. American Cas. Co., 127 Cal. App.2d 198, 269 P.2d 656 (1954), aff'd on rehearing, 127 Cal. App.2d 198, 273 P.2d 605 (1954); Adams v. City of New Haven, 13 I Conn. 552, 4 I A.2d III (1945) (dictum); Hummer v. School City of Hartford, I 12 N.E.2d 891 (Ind. App. 1953); Adkins v. Western \& So. Indem. Co., I 17 W. Va. 451, 186 S.E. 302 (1936); Board of Educ. v. Commercial Cas. Co., I 6 W. Va. 503, I 82 S.E. 87 (1935). Contra, Rogers v. Butler, I70 Tenn. 125, 92 S.W.2d 4 r4 (1936).

${ }^{23}$ There appears to be no question that a inunicipal government entity can insure against liability for "proprietary" functions. The leading case is Travelers Ins. Co. v. Village of Wadsworth, rog Ohio St. 440, 142 N.E. 900 (1924). However, the reasoning upholding such a purchase is that the function might be endangered by tort suits without the insurance. . 
to show that it was within the government entity's power so to spend public money. Similarly, in cases where the government entity seeks to recapture premiums paid on the ground that there has been a failure of consideration owing to its immunity from tort liability, the carrier is then at pains to show that something of value has been received. In all of these cases, nevertheless, the courts have uniformly decreed restitution. ${ }^{24}$

Quite apart from the cases where the policy insures the government entity against tort liability is the situation where the "named insureds" are government agents who ordinarily do not possess immune status. ${ }^{25}$ In these latter cases, the purchase of the insurance would appear to be well within the authority of government officials. Thus, the purchase of a policy insuring a school bus driver would seem to be an entirely appropriate and valid exercise of a school district's power to provide safe and efficient transportation of school children. To protect these children from the hazards of uncompensated injury arising from such transportation would appear to be as well indicated as procuring a fire-alarm system for the school building. Further cogency is added by the arguments that without such protection, competent and dependable employees might not be easy to find, and that such insurance is necessary for satisfactory labor-management relations. ${ }^{26}$

The statutes authorizing the purchase of liability insurance for immune government functions ${ }^{27}$ have generally been directed at specific

\footnotetext{
${ }^{24}$ See Burns v. American Cas. Co., 127 Cal. App. 198, 269 P.2d 656 (1954);
} Adkins v. Western \& So. Indem. Co., II W. Va. 451, I86 S.E. 302 (1936); Board of Educ. v. Commercial Cas. Co., II6 W. Va. 503, I82 S.E. 87 (1935).

${ }^{25}$ See note 38 infra.

${ }^{20}$ Only one case has been found in which these matters are discussed. Hartford Acc. \& Indem. Co. v. Wainscott, 41 Ariz. 439, I9 P.2d 328 (1933). This decision is the second earliest case discovered dealing with insurance and sovereign immunity from tort liability.

${ }_{27}$ The following is a listing of the statutes enacted to date: ARK. STATs. $\$ 66-517$ (1947); Cal. Vehicle Code ANN. \$ 400 (x956); Gen. Stat. Conn. Rev. $\$ 52-536$ (1958); Del. Code ANN. tit. 14, § 2904 (1953); FlA. Stat. ANN. $\$ 240.28$ (1957); GA. CODE ANN. \$§ 32-429, 32-431 (I952); IDAHo CodE ANN. \$§ 41-3304-06 (Supp. 1957); IND. Stat. ANN. \$ 38-1819 (1952); IOWA Code $\$ \S 368 A(12), 517 A(1)$ (1958); Kan. Gen. Stat. AnN. \$ 72-615 (Supp. 1957); Minn. Stat. Ann. \$\$ 471.4243 (Supp. 1958); Mont. Rev. Codes ANN. \$ 40-1204 (Supp. 1959); N.J. Stat. ANN. $\S$ 18:5-50.4 (Supp. 1958); N.M. STAT. ANN. $\S 64-25-8,9$ (1953); N.C. GeN. STAT. $\S$ 160-191.1 (1952); N.D. REv. CODE $\$ \S$ 15-4731, 39-0108 (Supp. 1953); Oнio Rev. CODE ANN. \$§ 307.44, 3327.09 (Baldwin 1953); OKI.A. STAT. tit. 69, § 30.1618, tit. $70 \$ 9.7$ (Supp. 1957); ORE. Rev. STAT. $\$ \$ 278.090,332.180$ (1953); PA. StaT. ANN. tit. 24, $\$ 7-774$ (I950), tit. 71, $\S 634$ (b) (Supp. 1958); S.D. LAws, C. I99 (1955); VT. LAws No. 243, § 5 (1949); VA. CODE ANN. \$§ 22.284-.294 
problem areas, principally the much-litigated school bus accident situation. ${ }^{28}$. Several of them go further, however, and authorize the insurance of all state-owned motor vehicles. ${ }^{20}$ Although most of these statutes are permissive only, in a growing number of states, liability insurance is mandatory. ${ }^{30}$ Characteristically, the government agents, either alone or together with the government entity, may be covered by the insurance. ${ }^{31}$ While only a few statutes expressly waive the immunity of the government entity from suit, ${ }^{32}$ under a number of other statutes, the insurer is specifically required to insert in the policy a promise that he will not raise the immunity defense. ${ }^{33}$

Even where the purchase of liability insurance is authorized ${ }^{24}$ or

(x950); WASH. REV. CODE, § 28.58.100(1I) (1950); W. VA. CODE ANN. § 1774(7) (Michie x949); Wis. Stat. \& 40.57 (x957); Wro. Comp. Stat. ANn. \& 67-647 (Supp. 1957).

${ }^{23}$ Every statute listed in note 27 supra, covers the school bus problem, with the exception of that of South Dakota. The following are states whose statutes authorize only school bus insurance: Delaware, Florida, Georgia, Idaho, Kansas, Minnesota, New Jersey, Pennsylvania, Vermont, Virginia, Washington, Wisconsin, and Wyoming. The states listed in note 29 infra, which have statutes authorizing insurance for motor vehicles owned by states, counties, or municipalities, include, of course, school buses.

${ }^{20}$ The following states authorize insurance for all state-owned motor vehicles: California, Connecticut, Indiana, Iowa, Montana, New Mexico, North Dakota, Oregon, Pennsylvania, Washington, and West Virginia. Some states have pressed further by authorizing insurance for motor vehicles owned by inunicipal or county governments, presuinably when they are engaged in iminune activities. These are Iowa, Minnesota, North Carolina, North Dakota, and Ohio. Statutes in two states, Arkansas and Oklahoma, permit direct action against the insurer or insurance purchased by governmental entities. This, by inference, would authorize the purchase of the insurance. See notes 44 and 45 infra.

${ }^{30}$ Statutes in the following states require that insurance be purchased: Delaware, Florida, Idaho, Oregon, Pennsylvania, Verınont, Virginia, Wisconsin, and Wyoming.

${ }^{31}$ See the statutes of California, Indiana, Iowa, Minnesota, New Mexico, North Dakota, Oregon, and Pennsylvania.

${ }^{32}$ Statutes expressly waive sovereign immunity froin tort liability to the extent of the insurance or contain language that should be so interpreted in Connecticut, Florida, Idaho, North Carolina, Virginia, Wyoming, and Wisconsin.

${ }^{38}$ Under some statutes, the carrier is simply required to make such a promise in the policy. Under some statutes, the particular provision that the carrier must include in the policy is specifically set forth. See, e.g., Florida, Georgia, Idaho, Indiana, Minnesota, Montana, New Mexico, and North Dakota.

${ }^{34}$ Courts may read a negative inplication into the legislation and conclude that the purchase of insurance is within the authority of the government entity only when it is permitted by statute. Consider Hummer v. School City of Hartford, $1 \times 2$ N.E.2d 891 (Ind. App. x953), where the court found no authority when a statute perinitted insurance on bus drivers, but the school district was the named insured on the policy. Operating on the assumption that liability of the carrier was contracted for by the government entity, the fact that the district rather than its agents was the named insured must 
where the issue of authority is not raised, ${ }^{35}$ however, the injured plaintiff still faces the major problem of enforcing the contract. There are three possible parties against whom the plaintiff may seek relief-the government agent whose tortious conduct injured him, the government entity, and the insurance carrier.

If the government agent is the named insured on the policy, either alone or together with the government entity, a judgment against him will be sufficient to render the carrier liable. ${ }^{36}$ Unless the jury can be made aware of the existence of the insurance which will indemnify the agent, however, it may be difficult for the plaintiff to obtain a judgment which will adequately recompense him-if, indeed, he obtains one at all. It is possible, moreover, that the government agent may be granted immunity by statute ${ }^{37}$ or judicial decision for acts within the scope of his duties. ${ }^{38}$ While this is not common, where the situation exists, no recovery at all is possible.

Ordinarily, an action against the carrier will be unsuccessful. It is

be considered a mistake caused by a failure on the part of the public officials to understand the significance of the formal parties to the contract.

${ }^{35}$ Relative to the number of cases involving insurance and sovereign immunity, there are few cases holding that there was no authority to obtain such insurance. Of these, one half were decided prior to 1936 . See note 22 supra.

${ }^{30}$ The courts have uniformly denied recovery against the government entity. Ayers v. Hartford Acc. \& Indem. Co., 106 F.2d 958 (5th Cir. 1939); Rittmiller v. School Dist., ro4 F. Supp. I87 (D. Minn. 1952); Schulte v. Hartford Acc. \& Indem. Co., 102 F. Supp. 68 I (D. Minn. 195 I); Jones v. Scofield Bros., 73 F. Supp. 395 (D. Md. 1947); Chambers v. Ideal Pure Milk Co., 245 S.W.2d 589 (Ky. App. 1952); Benton v. Board of Educ., 2or N.C. 653, 161 S.E. 96 (1931).

${ }^{37}$ See, e.g., the act in Bailey v. City of Knoxville, I I3 F. Supp. 3 (E.D. Tenn. 1953).

${ }^{88}$ In general, government agents are responsible for their own tortious conduct, even when it occurs in the course of their duties. However, occasionally the doctrine of sovereign immunity will be extended to a government agent on the rationale that the suit is one against the government. The doctrinal picture is rather confused. The courts purport to distinguish between acts which are "discretionary," or "quasi-judicial," in character, involving personal deliberation, judgment, and decision, and those which are "ministerial," amounting only to obedience to orders. The mantle of sovereign immunity has been drawn over the former, but not the latter. Further distinctions have been drawn between "authorized" conduct and acts "in excess of authority," and between "nonfeasance" and "misfeasance." See, generally, HARPER \& JAMEs, TorTs \$29.10 (1956); Prosser, TorTs 780-84 (2d ed. 1955); David, The Tort Liability of Public Officers, I2 So. CAL. L. Rev. 260, 368 (1939); Davis, Administrative Officers Tort Liability, 55 MICH. L. REv. 201 (1956); Jennings, Tort Liability of Administrative Officers, 21 Minn. L. REv. 263 (1937); Keefe, Personal Tort Liability of Administrative Officers, 12 FORD. L. REv. I30 (1943). 
universal practice for carriers to insert in the contract a provision such as the following: ${ }^{30}$

No action shall lie against the company until the amount of the damages for which the assured is liable by reason of any casualty covered by this policy is determined, either by final judgment against the assured, or by agreement between the company and the person or corporation making the claim.

And courts, fearful of undue jury liberality in a negligence suit where the carrier is joined as a defendant, ${ }^{40}$ have been careful to respect such provisions. Nevertheless, this obstacle has been circumvented in some states by the passage of a "direct action" statute which permits suit directly against the carrier, despite the "no action" clause. Under such a statute, the carrier's defense that the insured is immune is shortcircuited, as this defense is "personal" to the insured and not available to the carrier. ${ }^{41}$ While such a statute may have some desirable social effects, it is open to criticism on other grounds. ${ }^{42}$ Only one state, Louisiana, is known to have such a statute applicable generally to liability insurance. ${ }^{43}$ However, a "direct action" statute applicable only to insurance contracts with government entities immune from tort liability would afford a clean-cut and generally equitable resolution, and legislatures in the future may well adopt this approach. At present, only Arkansas ${ }^{44}$ and Oklahoma ${ }^{45}$ have enacted such a limited statute.

There remains the possibility that a direct suit against the carrier might be permitted on the grounds that the insurance contract is for the benefit of the injured third party plaintiff. The basic requirementthat an intention be shown to confer primary benefit upon the publicwould not be difficult to satisfy. The existence of the sovereign im-

${ }^{39}$ This particular clause was used in the contract in Hughes v. Hartford Acc. \& Indem. Co., 223 Ala. 59, I34 So. 46I (x93x).

${ }^{10}$ On the geueral subject of admissibility of evidence of insurance against liability, see MCCORMick, Evidence 355-58 (x954); Rapoport, Proper Discloseure During Trial that Defendant is Insured, 26 CoRnell L.Q. 137 (x940). See also Annot., 4 A.L.R.2d $76 x$ (1949).

${ }^{2}$ Rome v. London \& Lancashire. Indem. Co., $\times 69$ So. $\times 32$ (La. App. $\times 936$ ).

"The basic difficulty with "direct action" statutes is that juries are assumed to be excessively liberal in finding negligence and awarding high damage verdicts when the carrier is a defendant. This is thought unfairly to increase premium rates.

${ }^{4}$ LA. REv. Srat. $\$ 655$ (x950). See Comment, 13 LA. L. REv. 495 (x953).

"A ARK. Stat. \$ 66-517 (1947). See Aetna Cas. Co. v. Brashears, 226 Ark. ro17, 297 S.W.2d 662 (x956), where the statute was held constitutional as applied to an "indemnity" contract. See Jones, Direct Action Statutes and Jury Prejudice Against Insurance Companies, I1 ARK. L. REv. xo (x956).

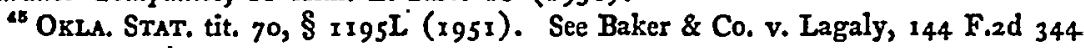
(10th Cir. 1944). 
munity rebuts the usual presumption that liability insurance is intended primarily to protect the insured, for here the government would be amply protected without it. And if the purchase of liability insurance were statutorily required, ${ }^{46}$ this would even more persuasively manifest an intention to protect the public.

To the degree that the intentions of the parties control, however, the "no action" clause would seem sufficient to bar a direct suit against the carrier, although it has been suggested that an indorsement on the policy by which the carrier promises not to raise the defense of immunity should be deemed to override the "no action" clause." And in the handful of cases in which this third party beneficiary theory has been advanced by counsel, the courts have so far uniformly rejected it. ${ }^{48}$ Looking to the supposed intentions of the parties, these decisions are understandable-for it is hard to see how the promise not to raise the immunity defense is inconsistent with the requirement of a judgment against the insured prior to suit against the carrier. And as a matter of policy, too, these rulings are supportable, provided that these courts do not also foreclose maintenance of an action against the insured government entity. To block both avenues of recovery would be indefensible.

Perhaps the most direct approach to the problem would be to modify the doctrine of sovereign immunity by carving out an exception where a

\footnotetext{
${ }^{10}$ Where insurance is required by statute to cover specific activities, some policies in the past have been construed to be for the benefit of third parties-the public-and claimants have been permitted to bring suit directly against the carrier. Malachowski v. Varro, 76 Cal. App. 207, 244 Pac. 936 (1926); Great Amer. Indem. Co. v. Vickers, 183 Ga. 233, I8S S.E. 24 (1936). These cases involved liability insurance on public carriers required by statute, and in both, the courts were faced with policies containing "no action" clauses. Liability insurance is now required of car owners in many states under financial responsibility laws, and yet direct actions against the carriers without first obtaining judgment against the insured are not permitted.

${ }^{48}$ It would seem that a better logical argument could be made where there is no such promise by the carrier, for then the sovereign immunity doctrine, read as part of the contract, would be inconsistent with the requirement of a prior judgment against the insured. If the court has previously determined that suits against the insured cannot be maintained, the prior judgment requirement should be dispensed with and a direct action suit against the carrier would be a proper solution. So far, no claimant in such circumstances has been known to have chosen this route. The addition of the endorsement derogates from this line of reasoning in that, with it, a suit against the insured government entity should be successful. While it is true that courts have so far denied recovery against the insured, despite the carrier's promise to waive immunity, see note $6_{3}$ infra, at least the courts cannot assume that in a later suit against the government entity, the carrier will violate its promise. See Schulte v. Hartford Acc. \& Indem. Co., I02 F. Supp. 68 I (D. Minn. 195I).

${ }^{48}$ Ford v. Glen Falls Indem. Co., 8o F. Supp. 347 (E.D.S.C. 1948); Hughes v. Hartford Acc. \& Indem. Co., 223 Ala. 59, I 34 So. 46I (1931).
} 
government entity has purchased liability insurance. The courts have seldom been asked to do this, and when asked, they have always denied the request. In as much as the existence of insurance is, by traditional jurisprudential thinking, not to be considered as an operative fact in determining liability, the courts have understandably balked at creating an exception on such a ground. ${ }^{49}$ But the courts have seldom explained their refusal on this basis; instead, they have usually taken refuge in the position that only the legislature has the power to change the law.

An alternative approach is the one almost universally debated in these cases-viz., by purchasing insurance, the government entity has waived its immunity and impliedly consented to be sued for the purpose of determining the liability of the carrier. Because the carrier is conducting the defense, no evidence of an express waiver by the government entity appears in these cases. The waiver is rather construed as follows: the purchase of insurance indicates an intention by the governinent entity that the carrier be liable; since the contractual complement necessary to achieve this is liability of the government entity, at least a limited waiver of sovereign immunity must have been intended. It thus becomes clear why so few cases involving municipal government entities have been litigated. Because such entities are liable for some of their activities, the courts have, where possible, indulged in the presumption that the insurance was intended to cover nonimmune activities; and, therefore, the waiver theory has been rejected.

The greatest obstacle to the effectiveness of the theory of waiver by the government entity is the notion that the power to waive immunity

"The problem at a deeper level may reflect a jurisprudential bias by courts against allowing themselves to be influenced by the existence of insurance. Our law has always prided itself on equality of treatment of rich and poor alike. In much of our legal history, this may have meant that the rich man is to be protected by law from worse treatment than that received by the poor man. Most courts have probably been scrupulous in refusing to allow the ability of the defendant to pay a judgment affect the determination of liability or the amount of damages. Certainly the formal doctrines of law and their rationales do not admit the relevance of such a factor as the ability to pay. But the underlying reasons for many legal doctrines are often heavily weighted by such factors as whether or not the defendant can bear the initial judgment, whether or not he can shift this loss in whole or in part to others, and who bears the ultimate risk, rather than the ornate and pious "Iegal" justifications for such doctrimes. When the underlying factors are significantly altered, and in certain areas of tort law, modern commercial development of liability insurance has accomplished this, it is unfortunate that the judges have failed to realize that the reasons for the traditional rules have changed and that justice now requires modification of these rules. Few examples of anachronistic doctrine can be found which are more striking than the sovereign immunity doctrine. 
resides exclusively in the legislature. ${ }^{50}$ It is upon this rock that nearly every attempt to enforce the insurance policy by suit against the insured government entity has foundered. ${ }^{51}$ It is not clear how or why this attitude took such firm root, or how or why sovereign immunity came to be regarded as anything other than a legal advantage susceptible of being modified contractually. The courts do not even bother to discuss the matter. Perhaps part of the answer lies in the scandalous history of local government graft and corruption of half a century ago. Still, it is difficult to visualize any modern policy considerations served by the rigid sovereign immunity doctrine that would not be equally protected by permitting a waiver through the purchase of liability insurance.

Because of the seemingly adamant requirement of positive legislative action, it has been argued that a legislative waiver may be adduced from statutes which authorize a government entity to purchase liability insurance covering an immune activity. It has been urged that the statute would otherwise be rendered nugatory. Although this argument would lose some of its force if the statute merely authorized the insurance of government agents, ${ }^{52}$ it is manifestly absurd for the courts to

\footnotetext{
${ }^{80}$ The traditional statement of this rationale is, "There is no provision of law for raising the funds with which to pay a claim not authorized or recognized by law." Boone v. Columbus, 87 Ga. App. 70x, 75 S.E.2d 338 (1953). This boils down to nothing more than the proposition that taxes cannot be raised for illegal expenditures, and such an expenditure is illegal. Thus, there are no legally available funds with which to "waive" the immunity. In as much as it assumes its own conclusion, this approach is hardly a convincing reason for denying the power of government entities to waive their sovereign immunity.

${ }^{82}$ Holland v. Western Airlines, Inc., 154 F. Supp. 457 (D. Mont. 1957); Rittmiller v. School Dist., xo4 F. Supp. I87 (D. Minn. I952); Jones v. Scofield Bros., 73 F. Supp. 395 (D. Md. 1947); Boone v. Columbus, 87 Ga. App. 701, 75 S.E.2d 338 (1953); Ford v. Caldwell, 79 Idaho 499, 32x P.2d 589 (I958); Hummer v. School City of Hartford, 112 N.E.2d 89x (Ind. App. 1953); Stucker v. Muscatine County, 87 N.W.2d 452 (Iowa 1958); Taylor v. Nevada, 31 I P.2d 733 (Nev. 1957); Cushman v. County of Grafton, 97 N.H. 32, 79 A.2d 630 (195 I); Livingston v. Regents of New Mexico College, 328 P.2d 78 (N.M. 1958); Marmor v. Port of New York Authority, 203 Misc. 568, x16 N.Y.S.2d x77 (Sup. Ct. 1952); Benton v. Board of Educ., zor N. C. 653, x6x S.E. 96 (x93x); Kesman v. Fallowfield Township, 345 Pa. 457, 29 A.2d 77 (1942); Boice v. Board of Educ., I1x W. Va. 95, 160 S.E. 566 (193I); Price v. State Highway Comm'n, 62 Wyo. 385, 167 P.2d 309 (I946).

${ }^{62}$ Although the thought was not expressed in the opinions, Rittmiller v. School Dist., 104 F. Supp. 187 (D. Minn. 1952), Chambers v. Ideal Pure Milk Co., 245 S.W.2d 589 (Ky. App. 1952), can be distinguished froun other cases in note 51 supra on this basis. It might appear that since in either situation the insurance premium is paid with public funds, no different legislative intent should be found where the statute permits the government agents to be insured, even if it is relevant logically. However, premiums for insurance covering government agents might be cheaper.
} 
deny enforcement of the insurance policy where the statute authorizes the government entity to procure insurance for itself only. While most courts to which this argument has been addressed have recognized its cogency, they have, nevertheless, with few exceptions, rejected it. ${ }^{.3}$ Their rationale has been that a waiver by statute must be clear and express, rather than implied. Thus, although the legislatures have not been too helpful in providing a solution to the problem, a share of the responsibility must be borne by the judiciary. ${ }^{64}$

Some practical difficulties, however, have been pointed out in justification of this seemingly doctrinaire judicial position. ${ }^{55}$ It has been suggested that problems would arise as to whether the government entity would be liable where a judgment exceeded the limits of the policy, ${ }^{50}$ or where the policy was not in force owing to such reasons as

${ }^{53}$ Rittmiller v. School Dist., 104 F. Supp. 187 (D. Minn. 1952); Hummer v. School City of Hartford, 112 N.E.2d 891 (Ind. App. 1953); Chambers v. Ideal Pure Milk Co., 245 S.W.2d 589 (Ky. App. 1952); Michael v. School Dist. of Lancaster, 391 Pa. 209, 137 A.2d 456 (1958); Utz v. Board of Educ., 226 W. Va. 823, 30 S.E.2d 342 (1944). Contra, Taylor v. Knox County Bd. of Educ., $292 \mathrm{Ky} .767$, ${ }_{167}$ S.W.2d 700 (1942). Two cases which discuss this issue are ensily distinguished because there was no insurance in litigation. Thomas v. Board of Educ. II N.J. 207, 94 A.2d 206 (1953); Texas Prison Bd. v. Cabeen, 159 S.W.2d 523 (Tex. Civ. App. 1942).

"This restrictive interpretation of the statutes follows the pattern of judicial obstruction in this field. Perhaps one-third of the states have at one time passed statutes permitting claims to be brought against the state and defining the procedure for the courts to follow. The courts, however, have uniformly refused to interpret such legislation as a waiver of immunity. Various rationales have been employed. One has been that the statutes contemplate only those claims for which relief was previously available -contract claims only. Another approach has been that "claims" are not "causes of action" and that although the statute permits the filing of suits against the state, it does not permit the recovery of damages. One commentator has summarized these decisions as granting a statutory permission "to visit the courthouse," Leflar \& Kantrowitz supra note 3 ; and another has questioned whether the legislature merely intended to permit claimants to file suit to "amuse themselves." Note, 5 CoRNELL L.Q. 340, 343 (1920). Another situation where the courts have narrowly construed legislative consent statutes is where an act creating a special government entity provides that the organization shall be authorized "to sue and be sued." While it is true that the language chosen by the legislatures has often not been unequivocal in waiving tort immunity, the evidence is also clear that the courts have been zealous in shielding the sovereign immunity doctrine. See Nutting, supra note 3 , at 5-7.

${ }^{55}$ See the opinion of Judge Chestnut, in Jones v. Scofield Bros., 73 F. Supp. 39\$ (D. Md. 2947).

${ }^{58}$ This objection does not appear to be serious for in states where recovery against the insurance proceeds is allowed, the trial judges have limited the judgment to execution against the insurance policy. See McCloud v. City of LaFollette, 38 Tenn. App. 553, 276 S.W.2d 763 (1954). See also, Thomas v. Broadlands Community School Dist., 348 Ill. App. 567, 209 N.E.2d 636 ( 5952 ). 
failure to present the claim within the time required by the policy, ${ }^{87}$ or where the carrier was insolvent. These supposed difficulties are, however, merely the result of conceiving the claimed waiver as a unitary idea; to limit the waiver to the extent of the available insurance proceeds would better accord with the probable real intention of the contracting government entity. ${ }^{58}$ If a waiver by the government entity were permitted, there would appear to be nothing inappropriate in allowing this intention to govern its extent. If the waiver were deemed to be accomplished by the legislature, a similar limited intention should not be difficult to presume. ${ }^{59}$

Even absent a clear and unambiguous statutory waiver of sovereign immunity, however, the courts of a few states have permitted recovery of a tort judgment against an insured, but otherwise immune, government entity. ${ }^{60}$ The most significant approach to the problem is that of

\footnotetext{
${ }^{57}$ Such problems do not seem insurmountable. In Rogers v. Butler, 170 Tenn. 125, 92 S.W.2d 414 (1936), the trial court permitted the plaintiff to recover a judgment against the insured board of education. The carrier declined to defend the suit, because notice of the claim was not submitted seasonably. The Supreme Court of Tennessee upheld the decision that the purchase of the policy "waived" the board's sovereign immunity, but modified the judgment so as to make it apply only to insurance proceeds. See also Tracy v. Davis, 123 F. Supp, 160 (E.D. Ill. 1954). In Utz v. Board of Educ, 126 W. Va. 823, 30 S.E.2d 342 (1944), in which the court held that the mere purchase of liability insurance did not waive sovereign immunity where the policy was inoperative owing to a mistake in reporting the accident to the carrier. While both this case and Rogers v. Butler, supra, may bring about the same result-the plaintiff recovers nothing except as against the government agent-one can see that it is not necessary to employ the rationale of the $U t z$ case.

t8 The so-called "municipal endorsement," see note 62 infra, which is featured in many of the recent cases, typically provides that the policy will not be in force if the claim exceeds a stated limit. This should be a sufficient showing of the limited intentions of the government entity.

${ }^{50} \mathrm{~A}$ number of the statutes which authorize the purchase of insurance, provide that the government entity is not to be liable in excess of the policy limits. See note 32 sipra.

${ }^{00}$ Note the development of the law in two jurisdictions, Kentucky and Tennessee, which adhere to the "waiver" doctrine. In Taylor v. Knox County Bd. of Educ., $292 \mathrm{Ky} \cdot 767,167$ S.W.2d 700 (1942), the court purported to be influenced by a statute showing a legislative intention to waive the immunity. In the later case of Standard Acc. Ins. Co. v. Perry County Bd. of Educ., 72 F. Supp. 142 (E.D. Ky. 1947), while the court relied on the Taylor case, it adopted the broad "waiver."

A similar development is to be noted in Tennessee. After finding statutory authority to purchase insurance in a provision permitting the board of education to require a bond of its bus drivers, the court found a "waiver" of the immunity. Rogers v. Butler, 170 Tenn. 125, 92 S.W.2d 414 (1935). See also City of Kingsport v. Lane, 35 Tenn. App. 183, 243 S.W.2d 289 (1951); Williams v. Town of Morristown, 32 Tenn. App. 274, 222 S.W.2d 607 (r949); Taylor v. Cobble, 28 Tenn. App. 167, 187 S.W.2d 648 (1945). In Bailey v. City of Knoxville, 113 F. Supp. 3 (E.D. Tenn. 1953),
} 
the Illinois courts, involving a substantive modification of the immunity concept itself. The formulation of this position is that sovereign immunity exists only for the protection of public funds, and its essence is the absence of a duty to pay an adverse judgment from public funds. Accordingly there need be no immunity from suit, as the immunity properly applies only to the execution of judgment. ${ }^{61}$ This approach not only comprehends the underlying reason for the sovereign immunity doctrine and shapes the defense according to that meaning, but also effectively evades the legal and logical pitfalls of the waiver argument-the lack of power of the government entity to waive, the problems of judgments in excess of the policy limits, the nonoccurrence of conditions precedent, and the carrier's insolvency.

In addition to the other contentions advanced by injured plaintiffs seeking to recover on the insurance policy, one argument has stemmed from the fact that in some cases, there has been an endorsement on the policy to the effect that the carrier will not raise the defense of sovereign immunity. ${ }^{82}$ This undertaking is plainly inconsistent with the

aff'd, 222 F.2d 520 (6th Cir. 1955), "waiver" by the government entity was found despite a statute providing immunity for the function. In McCloud v. City of LaFollette, 38 Tenn. App. 553, 276 S.W.2d 763 (1954), the court rejected the contention that recovery against the insurance proceeds was based on the use of "municipal endorsements," see note 62 infra, which were found in the litigated policies in Rogers v. Butler, supra, and City of Kingsport v. Lane, supra.

${ }^{01}$ This was accomplished in two stages. In Thomas v. Broadlands Community School Dist., 348 Ill. App. 567, 109 N.E.2d 636 (1952), the court permitted the plaintiff to recover a judgment against the school district to the extent of the insurance proceeds. While this is an excellently written opinion, the court is not explicit about the theory of the case. It expressly refused to decide the issue of the power of the government entity to waive its sovereign immunity, and it is arguable that its method was to create an exception when insurance existed. However, in the subsequent case of Tracy v. Davis, 123 F. Supp. 160 (E.D. Ill. 1954), the court denied a motion for demurrer in a suit against an immune government entity when the existence of insurance was not pleaded. The court interpreted Thomas v. Broadlands Community School Dist., supra, as holding that sovereign immunity did not bar the suit, only execution of a judgment and thus the existence of insurance was immaterial. It is to be expected that plaintiffs will not needlessly harass government entities by obtaining unenforceable judgments against them, but will only bestir themselves when there is an insurance fund to reach. Unfortunately, Tracy v. Davis, supra, is almost never cited, the theory of Thomas v. Broadlands Community School Dist., supra, has not been understood when it has been cited, and, as a result, perhaps, the Illinois approach has not had the influence it properly deserves. It is interesting to note that both of these Illinois cases were deeply influenced by the Illinois case of Moore v. Moyle, 405 Ill. 555, 92 N.E.2d 81 (1950), which is perhaps the best reasoned of the cases where recovery was permitted against an immune, but insured, charitable institution.

"2 A sample form of this so-called "municipal endorsement" is as follows: "It is agreed that the Company will not, when so requested by the Insured in writing, main- 
limitation on the carrier's promise to pay to the extent of "liability imposed by law on the insured." In the few cases in which the carrier's counsel, representing the insured government entity, has violated its agreement by urging this defense, however, the courts have permitted it, reasoning that the promise was made to and could be enforced by the insured only and not the plaintiff as a member of the public. ${ }^{63}$ Moreover, in these circumstances, the courts have held that the carrier, in defending the government entity, is not estopped from raising the defense and that this is not inconsistent with public policy. Where a statute forbids the carrier to raise this defense, however, no case has held that it may, not withstanding. ${ }^{64}$ On the other hand, no case as yet has unequivocally held the defense unavailable.

\section{Conclusions}

In general, the cases in this area demonstrate a high degree of judicial resistance to any modification of the sovereign immunity doctrine. Because the existence of insurance presents the courts with such an excellent opportunity to mitigate the unfortunate results of the doctrine, these cases testify to an underlying lack of sympathy with the notion that the risks of governmentally inflicted injuries to private citizens should be borne by society. The highly restrictive construction of ameliorative legislation further evidences this same attitude. The fact that most statutes are permissive rather than mandatory, however, indicates that the legislatures, too, are not totally committed to shifting

tain that the Insured is immune from liability by reason of having been engaged in a governmental, eleemosynary, or other function exempting it from liability as a matter of law." This particular form appeared in the policy in Schulte v. Hartford Acc. \& Indem. Co., 102 F. Supp. 681 (D. Minn. 1951).

${ }^{63}$ Jones v. Scofield Bros., 73 F. Supp. 395 (D. Md. 1947); Arnold v. Walton, 205 Ga. 606, 54 S.E.2d 424 (1949); Hummer v. School City of Hartford, 112 N.E.2d 891 (Ind. App. 1953); Stephenson v. City of Raleigh, 232 N.C. 42, 59 S.E.2d 195 (1950); Pohland v. City of Sheboygan, 251 Wis. 20, 27 N.W.2d 736 (1947). Cf., Standard Acc. Ins. Co. v. Perry County Bd. of Educ., 72 F. Supp. 142 (E.D. Ky. 1947); Taylor v. Knox County Bd. of Educ., $292 \mathrm{Ky} .767,167$ S.W.2d 700 (1942); City of Kingsport v. Lane, 35 Tenn. App. 183, 243 S.W.2d 289 (1951).

of The case of Hummer v. School City of Hartford, supra note 63 , so held, but the case is distinguishable. See note 34 supra. In two other cases, the courts refused to permit the plaintiff to recover despite such a statute. In each case, the court held that the statute did not apply, as the insurance was purchased before the act took effect. Both courts refused to be influenced by the policy import of the inapplicable statute, as they decided that the government entities possessed no power to waive sovereign immunity by purchasing insurance. Holland v. Western Airlines, Inc., I54 F. Supp. 457 (D. Mont. 1957); Ford v. Caldwell, 79 Idaho 499, 32 I P.2d 589 (1958). 
the risk of such injuries to taxpayers. The effect of these statutes, then, is to pass the policy choice on this issue back to the local government entities.

To the extent that state court judges recognize the injustices occasioned by the sovereign immunity doctrine, their refusal to modify it manifests a bias against creative activity by the judiciary in bringing an outmoded doctrine into accord with modern conditions and conceptions of justice. For judges to refuse to allow a recovery on an insurance policy as intended by the contracting government entity and the legislature and to take refuge in the sovereign immunity doctrine, when its only raison d'être-protection of public funds-is satisfied, pushes the rule beyond the logical limits of its principle. Judicial resistance to the movement in this area of law from the status of immunity to a norm of contract through insurance, points to the need for more affirmative and systematic state legislation.

Despite the fact that the courts have refused to permit an insurance recovery in the great majority of cases, the prospect is not unrelievedly gloomy. It is by no means impossible for government entities to obtain enforceable insurance. The purchase of liability insurance protecting government agents would seem to be within the authority of government entities, even in the absence of an enabling statute. Because its agents do not ordinarily share the government's immunity, legal stumbling blocks such as lack of power to waive the immunity are avoided. It is true that the extent of protection thus afforded the public is probably less than if the insurance were enforceable against the government entity, for absent a wealthy defendant, juries may be expected to be slower to find liability and to be less liberal with damage verdicts. However, even such protection as this is an improvement over no recovery at all.

There is one further possibility. Although courts have steadily denied the enforceability of liability insurance contracts covering immune governmental activities, all indications point to its increasing popularity. This suggests that at least some carriers and government entities may be entering into arrangements under which the carrier will assume liability and settle claims, but only for an amount which is, in its opinion, "just" compensation. If the facts of the claim are weak with regard to culpability or the damages asked are exorbitant, the carrier, perhaps with the permission of the government entities, may refuse to pay the claim and raise the sovereign immunity defense. In return for this advantage, perhaps the carrier may charge a lower rate. Settlement with claimants 
on such a take-it-or-leave-it basis would be efficient and economical. If such a practice exists to any large extent, it would be an interesting business solution to a vexing problem.

Despite the risk that the carrier may be arbitrary in its determination of responsibility for the injury or a reasonable amount of damages, the process suggested has commendable features. Because the injured party will never be permitted a jury verdict, the insurance premium rates should be lower than otherwise might be possible, and government entities should be more inclined to purchase such insurance. Only a few of the statutes authorizing the purchase of liability insurance have made it mandatory. Although legislative abandonment of sovereign immunity would be the most desirable solution to the problem, until this can be accomplished, this process presents an interim solution worthy of further investigation and consideration. At any rate, it is better than a vigorously-asserted sovereign immunity doctrine with its attendant low volume of insurance protection. If a greater degree of insurance protection is desired by government entities, the alternative would be to purchase a policy insuring nonimmune government agents.

Whether the sanctioning of liability insurance covering immune governmental activities will tend to retard progress toward a more general assumption of liability by government, or act as a catalyst and accelerate the progress, is a question not easily answered. Undoubtedly, the effectiveness of liability insurance in providing protection for both government agents and the public in the motor vehicle accident situation to some extent disarms the advocates of reform legislation. On the other hand, the added business may whet the appetite of the insurance industry to the point of inducing it to apply pressure in the legislature in behalf of statutes authorizing increased governmental assumption of tort liability. 